\title{
The Success of University Law Schools in England and Wales: Or How to Fail
}

\author{
Anthony Bradney \\ Keele University \\ a.bradney@keele.ac.uk
}

\section{$\underline{\text { Introduction }}$}

Legal academics in the England and Wales are often neither optimistic nor buoyant individuals. ${ }^{1}$ Some of the reasons for this are to do with the present situation in higher education. Thus, for example, precarious employment is as much a feature of contemporary law schools as it is of their parent universities. A number if commentators have noted the degree to which systemic introduction of casual employment contracts for academics has taken place in United Kingdom the universities. ${ }^{2}$ With the move away from the permanent employment comes "stress, [and] anxiety". ${ }^{3}$ Another more longstanding change in universities and their law schools has been the introduction of an audit culture which measures performance with respect to an ever-increasing range of indicators. The introduction of research audit in 1985 has been followed by a series of other forms of new audit processes at national, institutional and individual levels. ${ }^{4}$ The newest form of audit is the recent introduction of the Teaching Excellence Framework whose first results were announced in 2017. ${ }^{5}$ Each of these processes is significant in its own right but the cumulative result also needs to be considered. Burrows, for example, has argued that the metrics which are part of audit, taken together, produce "quantified control" of academic life. ${ }^{6}$ Ii is not that audit in universities is either wrong in itself or even new. Self-examination for both institutions and individuals is a desirable

\footnotetext{
${ }^{1}$ Many of the arguments in this article could also be made with respect to university legal education in the other jurisdictions in the United Kingdom. However, for reasons of space, this article is restricted to analysis of those law schools in England and Wales.

2 See, for example R Gill “Academics, Cultural Workers and Critical Labour Studies" (2104) 7 (1) Journal of Cultural Economy 12 at 18-19, C Bryson "What about the workers? The expansion of higher education and the transformation of academic work" (2004) 35(1) Industrial Relations Journal 35 at 40 and A Lopes and I Dewan "Precarious pedagogies? The impact of casual and zero-hours contracts in higher education" (2014) Journal of Feminist Scholarship 28.

${ }^{3}$ Gill op cit 19 . See also Lopes and Dewan op cit 32-35.

${ }^{4}$ For an examination of the history of this in relation to law schools see A Bradney "Conversations, Chances and Choices: The Liberal Law School in the Twenty-First Century" (Oxford, Hart Publishing, 2003) chp 7.

${ }^{5}$ See https://www.officeforstudents.org.uk/advice-and-guidance/teaching/tef-outcomes/\#/. As with other forms of university audit the reaction of the academy to the TEF has been at best ambivalent. See, for example, W Robinson and A Hilli “The English 'Teaching Excellence Framework' and Professionalising Teaching and Learning in Research-Intensive Universities: An Exploration of Opportunities, Challenges, Rewards and Values from a Recent Empirical Study" (2016) 14(21) Foro de Educacion 151.

${ }^{6} \mathrm{R}$ Burrows "Living with the h-index? Metric assemblages in the contemporary academy" $(2012) \wedge 0$ The Sociological Review 355 at 368.
} 
process. The axiom "know thyself" has an ancient lineage. ${ }^{7}$ Equally law schools and legal academics have not suffered from all of the adverse consequences of audit that are to be found in some other academic disciplines. ${ }^{8}$ Nonetheless both the specific failings of particular examples of audit together with the general conceptual misunderstandings that lies behind the current mania for such audit in the public sector has had deleterious effects on the lives of some legal academics. ${ }^{9}$ In this context it is perhaps not surprising that a number of contemporary legal academics report high levels of stress and anxiety. ${ }^{10}$ However an examination of the history of university legal education in England and Wales suggests that part of the reason for trepidation in legal academics may be deeper-rooted than the problems of the present-day.

In his obituary of Holland in 1975 Goodhart observed that

"...he [Holland] suffered from the same weakness to which a number of scholars at Oxford and Cambridge have succumbed - the fear of appearing in print in case they would subject themselves to criticism for some error of which they ought to have been aware."11

This "weakness" is not limited to Oxbridge legal scholars of the 1970s. Gardner has commented that "I'm sure all academics think that they are charlatans some days." 12 Whilst his remark is an exaggeration it does point to an important truth about the nature of the academic psyche. A person who does not simply reject out of hand Hume's argument that the proposition that the sun will not rise tomorrow is no less intelligible than that it will or who can comprehend the existential angst of Roquentin in Sartre's "Nausea" will always query apparent verities. ${ }^{13}$ The scepticism that lies at the root of the academic disposition makes doubt a prerequisite to every judgement. Everything we as academics do, say and write is continually in question. Academic freedom creates an obligation that makes us individually wholly responsible for all of our

\footnotetext{
${ }^{7}$ C Griswold Jr "Self-Knowledge in Plato's Phaedrus" (Pennsylvania State University Press, $2^{\text {nd }}$ ed, 1996).

${ }^{8}$ There is, for example, no evidence of research audit exercises promoting particular views of the nature of legal research as has been argued to be the case with economics (see, for example, F Lee, X Pham and G Gu "The UK research assessment exercise and the narrowing of UK economics" (2013) Cambridge Journal of Economics 693).

${ }^{9}$ On this mania and on the misunderstanding of the nature of audit on which it rests see M Power "The Audit Society: Rituals of Verification” (Oxford, Oxford University Press, 1997).

${ }^{10} \mathrm{C}$ Wilson and C Strevens "Perceptions of psychological well-being in UK legal academics" (2018) The Law Teacher (forthcoming).

${ }^{11}$ A Goodhart "Henry Arthur Holland: 1884 to 1974" (1975) 34 Cambridge Law Journal 1 at 3.

12 J Gardner "John Gardner Professor of Jurisprudence, University of Oxford” R Susskind (ed) "The Susskind Interviews: Legal Experts in Changing Times" (London, Sweet and Maxwell, 2005) p 264.

${ }^{13}$ D Hume "An Enquiry Concerning Human Understanding" (Oxford, Clarendon Press, 1975) pp 25-26. J Sartre

"Nausea" (Harmondsworth, Penguin Books, 1965).
} 
actions. ${ }^{14}$ What is vaunted today may be damned tomorrow. The agreement of our peers may show no more than that they share our errors. And, moreover, what is at risk, the accuracy of our judgements, is central to who we are as academics. In almost every instance this pressure is all to the good, pushing us to do ever better work. However, as the example of Holland above shows, there are occasions when the converse is the case. In relation to some questions excessive caution can lead to inaccurate judgements. In this article I will argue that this can be the case in the present day when the academic discipline of law assesses the overall quality of it work and then plans its future.

\section{Undergraduate Education in University Law Schools in England and Wales}

The web-site for York St John Law School, which advertises York St John as the "newest British law school", asserts that "[a] Law degree has universal recognition as a 'gold standard' qualification. Undoubtedly, it is one of the most popular degrees at University - consistently rating as one of the top courses in the UK." 15 How far can such a bold claim be justified?

One answer to this can be seen by looking at student application rates for the sector. In January 2009 there were 95,340 applications, in January 2017 122,700 applications and in 2918 127,640 applications. ${ }^{16}$ Law is a popular subject for prospective undergraduates and its popularity has risen over the years. Partially for this reason York St John University is not the only university to start a new law school in recent years. Thus for example the University of Roehampton opened its law school in 2014. ${ }^{17}$ The significance of the increase in the number of students seeking entry into law schools takes on greater import for their parent universities when it is looked at in the context of the fact that universities saw an overall decrease in applications for undergraduate courses of four per cent in 2017 and three per cent in $2018 .{ }^{18}$

If it is clear that law schools are popular in terms of undergraduate applications it is equally clear that law graduates on average get financial returns when they go into employment which are greater than those for graduates from most other academic disciplines. A 2016 Institute of Fiscal Studies is representative in its observation that, "[w]e find subjects like Medicine, Economics, Law, Maths and

\footnotetext{
${ }^{14}$ On this see further A Bradney "The Necessary Loneliness of Teaching (and of Being a Legal Academic)" in B van Klink and U de Vries (eds) "Academic Learning in Law: Theoretical Positions, Teaching Experiments and Learning Experiences” (2016) pp 83-85.

15 https://www.yorksj.ac.uk/schools/york-st-john-law-school/about-york-st-john-law-school/.

16 https://www.ucas.com/file/147861/download?token=v6pEGF8E.

${ }^{17} \mathrm{https} / / /$ pure.roehampton.ac.uk/portal/en/persons/giles-proctor(43abe598-1b2b-4228-acd1c1e17481de0c).html/.

18 https://www.theguardian.com/education/2018/feb/05/uk-universities-rise-in-applications-eu-students.
} 
Business deliver substantial premiums over typical graduates...". ${ }^{19}$ As this literature indicates, class of degree, gender and institution, amongst other things, all have an influence on graduate earnings for individuals but the general premium that exists for law graduates is clear. Moreover this financial return is not simply because law graduates become solicitors or barristers with high earnings; indeed, the converse is the case. First the earning capacity of both solicitors and barristers varies. Whilst some do receive significant financial rewards this is not true for all of them. ${ }^{20}$ Secondly, and more importantly, only a minority of law graduates go on to become solicitors or barristers. In 2017 there were 15,896 law graduates and 5, 719 new solicitor registrations. ${ }^{21}$ This ratio has remained constant for a number of years. ${ }^{22}$ In 2016/17 there were 474 new pupil barristers, this again being a figure that has been stable over the past few years. ${ }^{23}$ Were a law degree to lead just to being a solicitor or barrister the result would have been widespread unemployment for law graduates. The financial return for law graduates occurs because of the wide range of employment that they can enter into.

Neither the popularity of law amongst prospective undergraduates nor the financial returns that law graduates receive are an intrinsic measure of success. Indeed it is easy go further and to argue that since neither of these things relates to whether or not law graduates have inculcated that habit of mind which is at the centre of the aims of a liberal education neither are relevant to judgements about the success of law schools in providing undergraduate education. ${ }^{24}$ However to just argue this is to ignore the fact that the ability to attract undergraduates and the earning capacity of graduates have been by others as being indicators of success for an academic discipline. ${ }^{25}$ Using these widely,

\footnotetext{
${ }^{19}$ J Britton, L Dearden, N Shepherd and A Vignoles "How English domiciled graduate earnings vary with gender, institution attended, subject and socioeconomic background" (2016)

(https://www.ifs.org.uk/uploads/publications/wps/wp201606.pdf). See similarly I Walker and Y Zhu

"Differences by Degree: Evidence of the Net Financial Rates of Return to Undergraduate Study for England and Wales" (Lancaster, Lancaster University Management School, 2010) pp 13-14, G Conlan and P Patrignani "The Returns to Higher Education Qualifications" (2011) BIS Research Paper Number 45 passim and A Chevalier "Education, Occupation and Career Expectations: Determinants of the Gender Pay Gap for UK Graduates" (20017) Oxford Bulletin of Economics and Statistics 819 at 833.

${ }^{20}$ Law Society "Private practice solicitors' salaries 2016" (London, Law Society, 2017), Bar Standards Board "Barristers' Working Lives: A second biennial survey" (London, Bar Standards Board, 2013) chp 5. Gender, area of practice and geographical location are amongst the factors that affect earning capacity.

${ }^{21}$ The Law Society "Trends in the solicitors' profession: Annual Statistical Report 2017" (London, Law Society, 2018) Executive summary (http://www.lawsociety.org.uk/support-services/research-trends/annualstatistics-report-2017/).

${ }^{22}$ The Law Society "Trends in the solicitors' profession: Annual Statistical Report 2016" (2017) p 41 and p 44.

${ }^{23} \mathrm{https} / / / \mathrm{www}$. barstandardsboard.org.uk/media-centre/research-and-statistics/statistics/pupillage-statistics/.

${ }^{24}$ On this see further Bradney (2003) op cit) chp 4. On the prevalence of liberal education as the focus of teaching in university law schools in England and Wales see F Cownie "Legal Academics: Culture and Identities" (Oxford, Hart Publishing,2004) pp 75-78.

${ }^{25}$ Most recently see, for example, the speech by Sam Gyinah, the Minster for Higher Education, at the Higher Education Policy Institute's annual conference in 2018 (https://www.gov.uk/government/speeches/deliveringvalue-for-money-in-the-age-of-the-student). On the importance of the employability of graduates see amongst
} 
even though wrongly, accepted criteria the model for teaching in law schools in England and Wales is hugely successful. The literature about teaching in university law schools is rightly largely about what law schools could do better; it is about what is wrong, or what could be improved, not what is right. ${ }^{26}$ Law schools, however, do themselves a disservice if they do not acknowledge that by what have become conventional measures their basic model for undergraduate legal education is highly effective. ${ }^{27}$

\section{$\underline{\text { Research in University Law Schools in England and Wales }}$}

Whilst some legal academics can justify focusing on teaching at the expense of research, for the sector as a whole, if it is to thrive, research must be central to what it does. There is in this respect a dissymmetry between teaching and research both in university law schools and in their parent universities. If teaching is to take place there must be research of some form to base that teaching on. ${ }^{28}$ However, since knowledge is an end in itself, whilst research might be intended for the benefit of a particular audience it does not need such a goal. $^{29}$

Law schools in England and Wales have not always realised the importance of research. In 1975 Bridge observed that "[i]f academic lawyers are honest they will admit that there is too little legal research being done." ${ }^{30}$ Bridge was not alone in his concern. In the 1979 a survey by Aubrey Diamond, commissioned by the then Society of Public Teachers of Law, into the impediments for research in law schools was published. ${ }^{31}$ From the 1970 s onwards the attitude to the importance of research in law schools began to change, a process aided by the publication of the first Research Assessment Exercise in 1986 which first gave an external assessment of the quality of research in individual law schools. $^{32}$ In contemporary law schools research has an ever expanding prominence in an ever increasing number of law schools. The report on the last

\footnotetext{
other things Lord Browne "Securing a Sustainable Future for Higher Education" (2010) p 31 and Department for Business, Innovation and Skills "Students at the Heart of the System" Cm 8122 (London, The Stationery Office, 2011) p 38. On the concept of the successful university see M Shattock "Managing Successful Universities" (Maidenhead, Open University Press, 2010, $2^{\text {nd }}$ ed) chp 1.

${ }^{26}$ In this the literature follows the wider literature on learning and teaching in universities generally. See, for example, R Murray (ed) “The Scholarship of Teaching and Learning in Higher Education" (Maidenhead, Open University Press, 2008).

27 They also do themselves a disservice if they forget that these commonly accepted criteria are not merely wrong but are also slightly silly.

${ }^{28}$ K Jaspers "The Idea of the University” (London, Peter Owen, 1960) p 58.

${ }^{29}$ See further Bradney op cit chp 5.

${ }^{30}$ J Bridge "The Academic Lawyer: mere working mason or architect?" (1975) 91 Law Quarterly Review 488 at p 494.

${ }^{31}$ F Cownie and R Cocks “"A Great and Noble Occupation!' The History of the Society of Legal Scholars” (Oxford, Hart Publishing, 2009) pp 140-141.

32 See further Bradney op cit pp $182-186$.
} 
external assessment exercise noted that submissions included "10 HEIs submitting to Law for the first time." ${ }^{33}$ The report further noted that

"[t]he sub-panel received outputs judged to be of world-leading quality from over 85 per cent of submissions and the overwhelming majority of work submitted was of at least internationally recognised quality providing valuable knowledge to the field, confirming that excellent research and scholarship are being conducted in very many law schools across the United Kingdom." 34

Research is now integral to almost every university law school in England and Wales. The research that is done is pluralistic in nature responding, as Lewis puts it when looking at the wider university culture, to a combination of "research policy, disciplinary culture, and individual inclinations". ${ }^{35}$ Debate about the merits and value of individual outputs as well as different methods and theories is vigorous. One thing that cannot be seriously contested is the fact most law schools are now highly productive centres for research.

\section{What Can University Law Schools Say About Themselves?}

From the above it is clear that, for the sector taken as a whole, university law schools are, using commonly used criteria, highly effective both in terms of undergraduate education and research. There may be individual schools that fail in one or both areas but this is not the usual case. Notwithstanding this the claims that university law schools can truthfully and legally make about themselves are still very limited.

Closer consideration of graduate employment prospects illustrates the care and caution that law schools need to take when describing what they do. First, whilst graduate employment prospects may be good it does not follow that law schools can guarantee employment in a particular sector. Thus, for example, many law schools will be able to give examples of graduates who have gained traineeships in leading firms of solicitors. The largest tranche of trainee solicitors starting each year have long been employed by very large firms. ${ }^{36}$ It is unlikely, however, that any law school could say that every one of its graduates who sought employment with such firms was successful. Secondly,

\footnotetext{
33 "Research Excellence Framework 2014: Overview Report by Main Panel C and Sub-panels 16 to 26)" (2015) p 70.

(https://www.ref.ac.uk/2014/media/ref/content/expanel/member/Main\%20Panel\%20C\%20overview\%20report.p df).

34 "Research Excellence Framework 2014: Overview Report by Main Panel C and Sub-panels 16 to 26)" loc cit

35 J Lewis “Academic Governance: Disciplines and Policy”(2018) p 168. On the width of research done in university law schools see Cownie op cit at pp 54-60 and pp 133-138.

${ }^{36}$ See, for example, The Law Society (2017) op cit $\mathrm{p} 47$.
} 
whilst most law schools might be able to make claims about the possibility of employment as a trainee solicitor this does not mean that they can make any claims about the satisfaction that their graduates will gain from that employment. To continue with the example of very large firms of solicitors employment in such firms will bring with it significant financial rewards. ${ }^{37}$ However the research into these firms is replete with accounts of those who are discontented with their employment. Smith's pseudonymous description of work as a trainee solicitor as well as reports of drop-out rates amongst solicitors in such firms all suggest a job sector which is far from happy. ${ }^{38}$ Graeber's study "Bullshit Jobs" uses the corporate lawyer as an illustration of the phenomenon he is analysing. ${ }^{39}$ Work in this sector is neither necessarily worthwhile nor fulfilling for those employed within it. Houellbecq's reflection, "[w]hat could possibly incite human beings to undertake tedious, tiresome tasks? This seemed to me the only political question worth asking", seems to be pertinent here. ${ }^{40}$ Nor is this argument confined to employment as a corporate lawyer; similar conclusions about dissatisfaction in employment, for somewhat different reasons, can, for example, be drawn in relation other types of solicitor. ${ }^{41}$ The issue is a general one. Law schools may be able to provide evidence of employability for their students. They cannot suggest that that employability also necessarily leads to, or even allows, human flourishing. ${ }^{42}$ Thoreau's nineteenth century statement that "[t]he mass of men lead lives of quiet desperation" is applicable to twenty-first century law graduates. ${ }^{43}$ Law schools are highly successful in terms of undergraduate education but what they are successful at does not necessarily improve the lives of their graduates. ${ }^{44}$

The moral duty that law schools have to be accurate in their descriptions of themselves is also a legal duty. Two separate complaints made to the Advertising Standards Authority about claims made by the University of Law

\footnotetext{
${ }^{37}$ The Law Society "Private practice solicitors' salaries 2016: PC Holder Survey 2016" (2017) p 7.

${ }^{38}$ A Smith "Vicious (Magic) Circle" (2006) 9 Legal Ethics 152. Faulconbridge and Muzio report attrition rates of 23 per cent for "large English firms" (J Faulconbridge and D Muzio "Financialisation by Proxy": The Case of Large City Law Firms" in H Sommerlad, S Harris-Short, S Vaughan and R Young "The Futures of Legal Education and the Legal Profession" (2015) p 54.

${ }^{39}$ D Graeber "Bullshit Jobs: A Theory" (London, Allen Lane, 2018) p 36.

${ }^{40}$ M Houellbecq "Platform" (London, William Heinemann, 2002) p 239.

${ }^{41}$ See, for example, legal aid solicitors (D Newman "Legal Aid Lawyers and the Quest for Justice" (2013) pp 56-57). The problem is not unique to being a lawyer; instead it is general if not universal. As one respondent puts it in Graber's study, "good Lord, the working world is crap" (Graeber op cit p 130).

${ }^{42}$ The right to, or even the obligation to seek, a flourishing life has been the subject of extensive analysis. See, for example, J Finis "Natural Law and Natural Rights" (Oxford, Clarendon Press, 1980) particularly in chapters III and IV.

${ }^{43}$ H Thoreau "Walden or Life in the Woods" (New York, Rinehart \& Co, 1948) p 5. Equally applicable are Sennett's strictures on the consequences of an individual not being able to engage in what he calls craftwork (see R. Sennett "The Craftsman" (London, Allen Lane, 2008) particularly in the final chapter).

${ }^{44}$ The liberal education that most legal academics claim to provide is potentially central to human flourishing (see Bradney (2003) op cit pp 52-56). Whether they are successful in providing this education is more difficult to assess than their success in ensuring employability.
} 
show what can happen when a law school is found not to comply with this duty. One complaint was made about what the University of Law seemed to be saying about the salaries of its graduates. The other complaint was about the University of Law's description of itself as being 'the UK's leading law school". ${ }^{45}$ In both instances the Advertising Standards Authority followed its standard practice and asked what evidence there was to substantiate the statements that were being made. According to the Authority's Code of Practice advertisers "must hold documentary evidence to prove claims that consumers are likely to regard as objective and that are capable of objective substantiation" 46 . When the University of Law could not provide evidence that satisfied the Advertising Standards Authority the University of Law were told that the relevant advertisements could not appear again and that similar such claims should not be made unless the University of Law could provide evidence to support them.

It is not just the Advertising Standards Authority rulings themselves that are important for university laws schools; as significant are the identities of the complainants, described in the rulings as a university law lecturer and a retired university law professor. On the one hand the Advertising Standards Authority's is a regulatory system for university law schools. In this it is akin to the work of the Competition and Markets Authority or the benchmarking process in setting standards for law schools. ${ }^{47}$ However the Advertising Standards Authority's jurisdiction can also help legal academics to regulate themselves by challenging inaccurate claims. A complaint made to the Advertising Standards Authority by the Nightingale Collaboration illustrates how this can be done. The Nightingale Collaboration complained successfully about a leaflet issued by University College Hospitals on the subject of the efficacy of Western herbal medicines. ${ }^{48}$ The purpose of the Nightingale Collaboration is to "challenge questionable claims by medical practitioners". ${ }^{49}$ The ASA's website lists four successful complaints against various institutions made by the Nightingale Collaboration. ${ }^{50}$ The precedent for the future use of the Advertising Standards Authority jurisdiction by either individual legal academics or professional associations is thus clear.

\section{$\underline{\text { How to Fail as a Law School }}$}

\footnotetext{
45 ASA Adjudication on The University of Law Ltd and Marketing VF Ltd (https://www.asa.org.uk/rulings/theuniversity-of-law-ltd-and-marketing-vf-ltd-a16-346902.html).

${ }^{46}$ ASA "Code of Practice" 3.7.

${ }^{47}$ https://www.gov.uk/government/organisations/competition-and-markets-authority. www.qaa.ac.uk/docs/qaa/subject-benchmark-statements/sbs-law-15.pdf?sfvrsn.

${ }^{48}$ ASA Adjudication on University College London Hospitals t/a The Royal London Hospital for Integrated Medicine https://www.asa.org.uk/rulings/university-college-london-hospitals-a11-166636.html

${ }^{49}$ https://www.nightingale-collaboration.org/.

${ }^{50}$ https://www.asa.org.uk/search.html?q=Nightingale+Collaboration.
} 
The recent history of law schools in the USA shows how it is possible to fail as a law school. The model of legal education traditionally followed in the USA is very different from that followed in England and Wales. ${ }^{51}$ The law degree has largely been seen as being an education for the aspiring lawyer. ${ }^{52}$ Law schools have charged students high fees, law graduates expecting to be able to pay off the resultant debt by getting employment as highly paid lawyers. ${ }^{53}$ However, in part as a result of the economic events of 2008 and subsequent years, such jobs have become less readily available. ${ }^{54}$ A consequence of this has been that law schools have found it harder to attract new students with some prospective students beginning to question the value of legal education. ${ }^{55}$ A number of graduates have even begun legal actions against their law schools, feeling that their prospects were misrepresented to them. ${ }^{56}$ The failing model of American law schools as an educational enterprise has also created problems for its research mission. Amongst many proposals for improving the position of law schools has been the suggestion "[n]ot all law schools and not all law professors must be oriented towards research" with the aim of making them cheaper to run. ${ }^{57}$

\section{$\underline{\text { Conclusion }}$}

Over the decades there have been various reports which have sought to influence university law schools. ${ }^{58}$ The latest such review, the 2013 Report of the Legal Education and Training Review, commissioned by the Bar Standards Board, ILEX Professional Standards and the Solicitors Regulation Authority,

\footnotetext{
${ }^{51}$ On the history of American law schools see R Stevens "Law School: Legal Education in America from the 1850 's to the 1980's" (University of North Carolina Press, 1987).

${ }^{52}$ P Campos "The Crisis of the American Law School" (2012) 46 University of Michigan Journal of Law Reform 177 at $\mathrm{p}$ 198. This is not a universal view. In an exchange about the place of Critical Legal Studies in American law schools Owen Fiss argued that "[1]aw professors are not paid to train lawyers, but to study law and to teach their students what they happen to discover" (P Martin (ed) "Of Law and the River and of Nihilism and Academic Freedom" (1985) 35 Journal of Legal Education 1 at p 26).

${ }^{53}$ Readily available federal loans mean that immediate living costs and tuition fees for students can be met by them (D Jones Merritt and D Merritt "Unleashing Market Forces in Legal Education and the Legal Profession" (2013) 26 Georgetown Journal of Legal Ethics 367 at p 368).

${ }^{54}$ Campos has estimated that in 2011 only 15 per cent of law school graduates were getting "high paying" employment with less than 50 per cent getting "real legal jobs" (Campos op cit p 204 and p 202). Tamanaha has argued that many law schools have consistently over-estimated both employment rates for graduates and the salaries that they have earned (B Tamanaha "Failing Law Schools" (Chicago, University of Chicago Press, 2012) pp146-154).

${ }^{55}$ R Tejani “Law Mart: Justice, Access, and For-Profit Law Schools" (Stanford, Stanford University Press, 2017) pp90-91.

${ }^{56}$ B Tamanaha "The Problem with Income Based Repayment, and the Charge of Elitism: Responses to Schrag and Chambliss" (2013) 26 Georgetown Journal of Legal Ethics 521 at p 525.

57 Tamanaha (2012) op cit p 61. At least one university is reported as having cut research budgets in response to Tamanaha's suggestion (Tejani op cit p 94).

${ }^{58}$ See, for example, the Report of the Ormrod Committee on Legal Education (Cmnd 4594, 1971) "A Time for a Change: Report of the Committee on the Future the Legal Profession (the Marre Report) (London, The General Council of the Bar, 1988) and Advisory Committee on Legal Education "First Report on Legal Education and Training" (1996).
} 
concluded that there was "substantial evidence of the strength of the system [of legal education and training for the legal professions]".59 Given this it is unsurprising that the Bar Standards Board's subsequent proposed changes to the process of qualifying as a barrister are incremental in their nature, having relatively few implications for the undergraduate law degree. ${ }^{60}$ In contrast the Solicitors Regulation Authority's proposed Solicitors Qualify Examination has been described as a "radical shake-up". ${ }^{61}$ Much about this new assessment, even at a very basic level such as examples of questions that will be set, remains unclear. $^{62}$ The Legal Services Board has not yet decided whether to permit the change to proceed. ${ }^{63}$

The SQE, if introduced, will not have any direct impact on law schools. Law graduates will have to take a further examination after their degree in order to qualify as a solicitor. However this is the situation under the current routes for qualification. ${ }^{64}$ Only if law schools choose to align their teaching with the new examination, if law degrees become degrees to become a solicitor, will the SQE have an influence on law schools. ${ }^{65}$ But there is no obvious reason why the sector would change its proven model of legal education. Law schools have been successful by not tying themselves to a particular employment sector. Becoming a solicitor is what a minority of law graduates do. To offer law degrees which were simply degrees to become a solicitor would be to guarantee, as in the USA, some disappointed and possibly litigious graduates. Individual law schools might, in the future, try to allege particular advantages for their law degree in passing the SQE. However the stronger the claim made the more robust would need to be the evidence to justify it to the Advertising Standards Authority. Moreover such schools would not have any evidence about the employability of their new graduates when, as would inevitably happen with some, they failed to become solicitors. ${ }^{66}$ Law schools in England and Wales

\footnotetext{
${ }^{59}$ Legal Education and Training Review "Setting Standards: The Future of Legal Services Education and Training Regulation in England and Wales" (2013) p 62.

${ }^{60} \mathrm{https} / / / \mathrm{www}$. barstandardsboard.org.uk/qualifying-as-a-barrister/future-requirements/future-bartraining/future-ways-to-qualify-as-a-barrister/academic-learning/.

${ }^{61} \mathrm{M}$ Davies "Changes to the training of English and Welsh lawyers: implications for the future of university law schools" (2018) The Law Teacher 100.

${ }^{62}$ For information from the Solicitors Regulation Authority on the new assessment see https://www.sra.org.uk/sra/policy/sqe.page

${ }^{63} \mathrm{https} / / /$ www.legalservicesboard.org.uk/news_publications/LSB_news/PDF/2018/20180327LSB_Approves_SR A_SQE_Application.html.

${ }^{64}$ https://www.sra.org.uk/faqs/contact-centre/students/resources/01-I-want-to-qualify-as-a-solicitor/howqualify-solicitor.page.

${ }^{65}$ On the possible impact if this were to happen see J Gibbons "Policy recontextualization: The proposed introduction of a multiple-choice test for the entry-level assessment of the legal knowledge of prospective solicitors in England and Wales, and the potential effect on university-level legal education" (2017) 24 International Journal of the Legal Profession.

${ }^{66}$ In the US context Campos suggests that having a law degree can hamper getting employment outside the legal sector (Campos op cit p 198).
} 
have a model that has allowed the sector to fulfil its aspirations in terms of both teaching and research. Changing the model would mean the sector failing. 